\title{
Methods for Protecting Hotels Against Rodents
}

\author{
Abd El Aleem Saad Soliman Desoky* \\ Plant protection Department (Agricultural Zoology), Egypt \\ *Corresponding author: Abd El Aleem Saad Soliman Desoky, Plant protection Department (Agricultural Zoology), Egypt
}

\begin{abstract}
The study is interested in mentioning the most important signs of rodents in hotels and the most important areas where rodents can be found inside the hotel. The study also aims at clarifying the most important dangers of rodents in the hotels and the most important preventive methods that can be used in the integrated management program for controlling rodents inside the hotel.
\end{abstract}

Keywords: Signs of Rodents; Hotels; Important Dangers; Preventive Methods; Controlling Rodents

\section{Introduction}

Rats and mice can be a major pest problem in buildings. They damage food, documents, and clothing. Damage to a structure occurs when rats and mice gnaw on structural components, including wiring, wood, and plastics. The gnawing on wire insulation can result in electrical shorts and fires. Rodents have also been implicated in the spread of dangerous human diseases. In short, structural risks, health risks, and a general lowering of environmental quality accompany any rodent infestation [1-3].

\section{Signs of Rodents in Hotels}

a) Droppings: Rodent droppings are a sure sign that rats or mice are present, and will indicate the type of rodent, the size of the infestation, and where they are most active. Mouse droppings are small, less than one quarter inch, and pointed on both ends. Rat droppings are half an inch or larger. Norway Rat droppings are blunt at both ends, while Roof Rat droppings are having pointed ends. New droppings are shiny and puttylike in texture, while old ones are hard and crumbly. Varying feces sizes indicate that juveniles and adults are present, and lots of droppings may be an indication of a large infestation. The location of the droppings indicates active areas where you should place bait or traps.

b) Urine Odor: Rodent urine has a strong musky odor. With large infestations you can easily smell it.

c) Gnawed Holes: Gnawed mouse holes are small, clear-cut, and about the size of a dime. Gnawed rat holes are large, about the size of a quarter, with rough torn edges. d) Rub and Gnaw Marks: Oily rub marks are left in places where rodents travel along walls. If rub marks smear, you know they are fresh. Gnaw marks on wood around the house also are a sign. Tooth marks about one eighth inch long are typical of rats and small scratch marks are a sign of mice.

e) Runways: Common rodent pathways are generally along interior walls, building foundations, ledges, pipes, electrical wires, conduits, tree branches and fence rails.

f) Nests: Mice will shred paper, string, and other pliable materials to build their nests indoors. Norway rats nest outdoors in burrows deep in the ground. Roof rats typically nest above ground in attics, trees, or dense vegetation.

g) Noises: Rodents are nocturnal. At night they often create scratching sounds as they run inside walls and along floors.

h) Pet Behavior: Pets tend to act unusual when they hear or smell rodents in the house. They may appear extremely alert, bark, or begin to paw at spaces beneath refrigerators, stoves, or low-clearance pieces of furniture [4].

\section{Areas of Rodent Activity}

a) Food storage areas.

b) Hotel kitchens.

c) Public and employee laundry facilities.

d) Storage and supply closets.

e) Loading docks. 
f) Waste disposal areas [5].

\section{Risks Associated with Rodent Infestation}

a) Food contamination \& disease transmission.

b) Health threats to hotel employees and guests.

c) Failed inspections possibly resulting in temporary or permanent closure.

d) Damage to the reputation of the hotel.

e) Property damage to the hotel structure, wiring \& furnishings.

f) Financial loss resulting from damage to both the hotel's property \& reputation [5].

\section{Methods for Protecting Hotels against Rodents}

a) The most important steps in controlling rodents are preventive methods because prevention is better than control [2]. A professional company can help create tailor-made plans for prevention in your facility, which can be distributed throughout the hotel [3].

b) Healthy buildings should be constructed to prevent the entry of mice and rats.

c) Repair/seal any cracks or holes small diameter or inch or larger in the foundation, walls [2].

d) Repair broken windows and doors - Make sure that the door seals are tight for any inhabited buildings.

e) Place the wire on all building windows.

f) Rats can enter the hotel through cracks and crevices, so sealing the building from the outside is paramount to your pest control success [3].

g) In occupied buildings, all possible access areas should be identified by rodents [2].

h) Cracked or unusual food will be cleaned and removed from the intake area at the end of each day [1].

i) All trash cans should have tightly sealed lids and garbage should be removed from the premise's multiple times per day.

j) Garbage containers are emptied in the dining areas daily. k) There will be no garbage dumps in the uninhabited buildings.

l) The external garbage areas will remain clean and devoid of organic debris on the ground.

m) All edible foods (lunch and snacks) will be stored in rodent-resistant containers.

n) Remove rodent attractions such as food or shelter by ensuring that the food is stored safely, and that the surrounding environment is clean.

o) Maintain a clean hotel environment.

p) The Large hotel usually have multiple food preparation and dining areas. All of these locations should have strict cleanliness guidelines similar to any restaurant for staff to ensure that no scraps or trash are left accessible to rodents.

q) Visitors rooms should also be cleaned on a daily basis if Visitors are being fed in their rooms. Visitors should be reminded that snacks left behind are tempting to pests as well.

r) Debris and shrubbery along the hotel walls should be removed (if possible) to eliminate hiding places for colonies of pests entering the building, especially during the fall and winter months.

s) A professional pest control company can help identify problem areas that should be upgraded.

t) Chemical control of pests, bait loaded traps, and the disposal of dead rodents should always be administered by a professional pest control company.

\section{References}

1. Desoky ASS (2018) Review: Rodent Control Strategies in Houses. International Journal of Research Studies in Agricultural Sciences (IJRSAS) 4(3): 28-31.

2. Desoky ASS (2018) Integrated Pest Management for Rodent in Buildings. Current Investigations in Agriculture and Current Research 4(4).

3. Desoky ASS (2019) Review: Rodent Control Strategies in Hospitals (In press).

4. https://www.tomcatbrand.com/en-us/library/identifying-mice-rats/ identifyingmouse-or-rat-problem-your-house.

5. https://www.westernpest.com/commercial-pest-control/hotels/sixhotel-hotspots-for-rats-mice/.

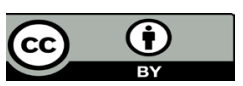

This work is licensed under Creative Commons Attribution 4.0 License

To Submit Your Article Click Here: Submit Article

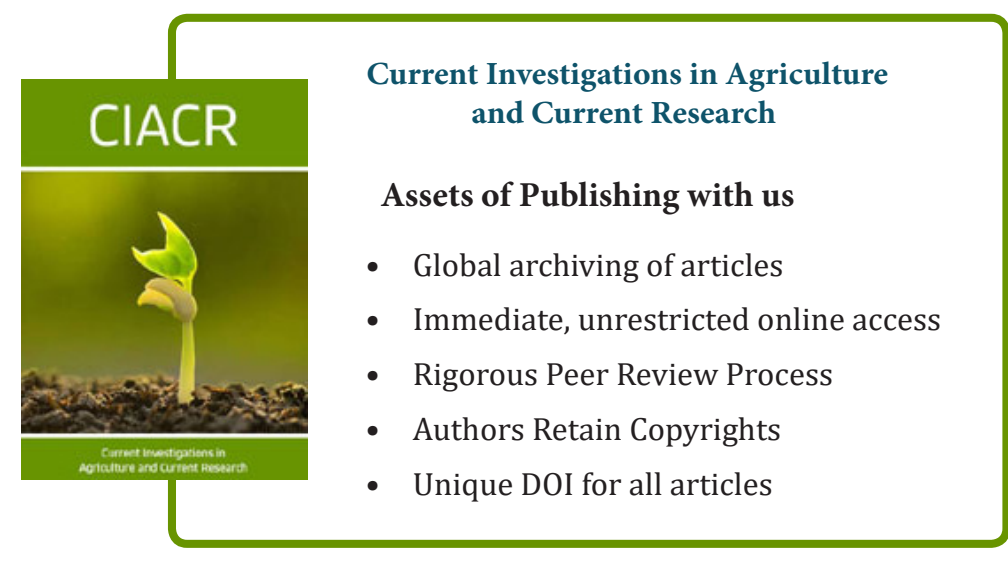

